\title{
Effect of Potassium and Sulphur on Nutrient Uptake, Yield and Quality of Safflower in Vertisol
}

\author{
Dipak Salve, Monika S. Bhavsar, Rajanikant B. Ghagare and Sugandh N. Shinde
}

Soil Science and Agricultural Chemistry Section, College of Agriculture, Nagpur (M.S.), India

*Corresponding author

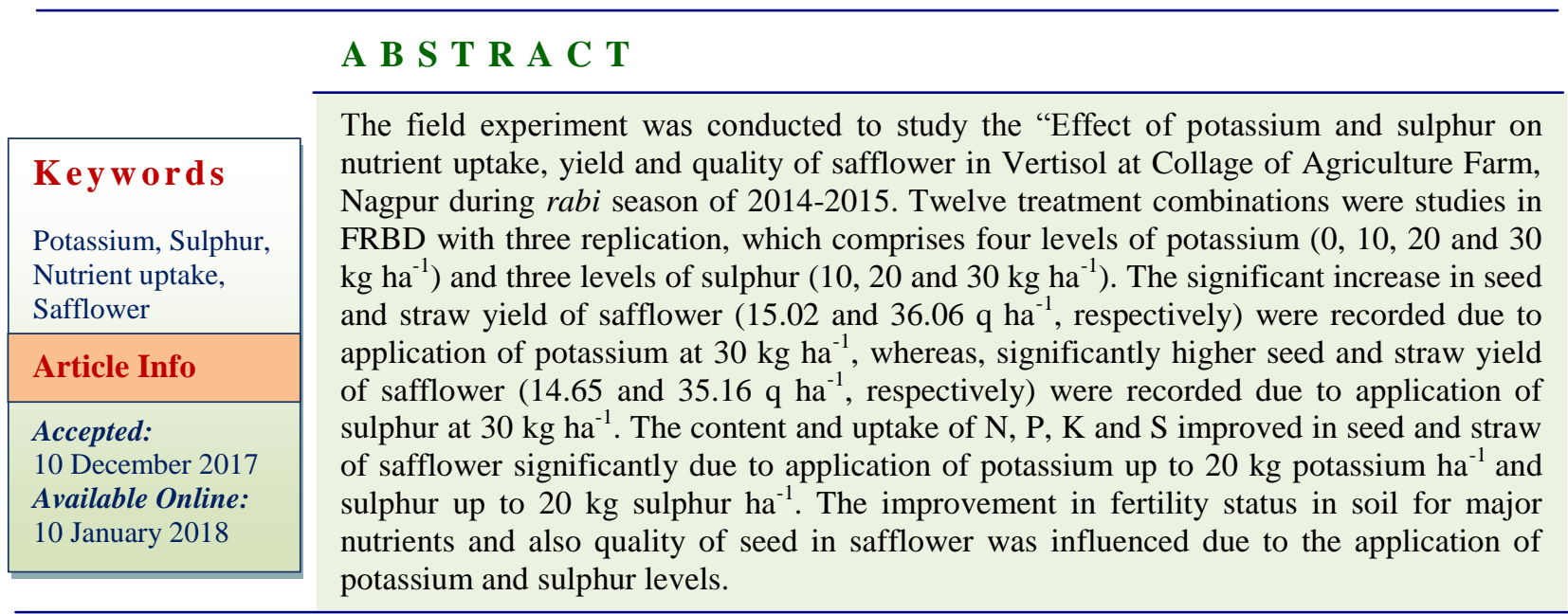

\section{Introduction}

Safflower (Carthamus tinctorius L.) is an important edible rabi oilseed crop of India, widely grown on large scale. Low cost of production and high yield potentials hold promise for its large scale cultivation in the country (Chiddha Singh, 1998).

The seed contains $24-36 \%$ oil and the protein content of the whole seed ranges from 11$24 \%$. High oleic oil is a beneficial agent in the prevention of coronary artery disease (Dajue and Mundel, 1996). In the world it was cultivated over an Area 0.964 million hectare, and had a production of 0.651 million tonnes with average productivity of $827.9 \mathrm{~kg} \mathrm{ha}^{-1}$ (Anonymous, 2014). India is the largest producer of safflower in the world, By making the $29.2 \%$ of world's safflower production, India is placed on the top (Ekin, 2005).

Saalbach (1973) reported that, sulphur deficiency tends affect adversely the growth and yield of seed crop, which reduces the crop yield to an extent of 10-30\%.for oilseed, potassium and sulphur are most vital nutrient for the growth and development of safflower crop. Besides $\mathrm{N}$ and $\mathrm{P}$, the use of $\mathrm{K}$ has been reported to influence the productivity of seed yield and seed oil content (Ghosh et al., 1995) 
Kau and Chen (1980) reported that K increase the seed oil content of towar var. of rapeseed. Kandalp and Chandel (1993) also reported that application of $\mathrm{K}$ improved of rapeseed. Sulphur is master nutrient of oil seed production, it is essential for protein production because, it is constituent of three main amino acid viz., cystine, cysteine, methionine. The available sulphur content of majority of soils of in the country is already low because of low organic matter build up and increase loss of $\mathrm{SO}_{4}$ sulphur through leaching and erosion. The oil seed crop require more quantity sulphur than cereals.so deficiency of sulphur occurs in the soils (Singh and Sahu, 1986).

\section{Materials and Methods}

The field experiment was carried out at experimental field at EAD farm, College of Agriculture, Nagpur. The experiment was laid out in FRBD with sixteen treatment combinations each replication thrice. Treatment combination are $\left(\mathrm{T}_{1}+\mathrm{T}_{2}+\mathrm{T}_{3}, \mathrm{~K} @\right.$ $0 \mathrm{~kg} \mathrm{ha}^{-1}+\mathrm{S} @ 10,20,30 \mathrm{~kg} \mathrm{ha}^{-1}, \mathrm{~T}_{4}+\mathrm{T}_{5}+\mathrm{T}_{6} \mathrm{~K}$ @ $10 \mathrm{~kg} \mathrm{ha}{ }^{-1}+\mathrm{S} @ 10,20,30 \mathrm{~kg}$ $\mathrm{ha}^{-1}, \mathrm{~T}_{7}+\mathrm{T}_{8}+\mathrm{T}_{9} \mathrm{~K} @ 20 \mathrm{~kg} \mathrm{ha}^{-1}+\mathrm{S} @ 10,20,30$ $\mathrm{kg} \mathrm{ha}{ }^{-1}, \mathrm{~T}_{10}+\mathrm{T}_{11}+\mathrm{T}_{12} \mathrm{~K} @ 30 \mathrm{~kg} \mathrm{ha}{ }^{-1}+\mathrm{S} @$ $\left.10,20,30 \mathrm{~kg} \mathrm{ha}^{-1}\right)$.

Recommended dose of fertilizer 40:40:00 kg NPK ha ${ }^{-1}$ was applied in the form of P-DAP, N-Urea. Three levels of S @ 10, 20,30 kg $\mathrm{ha}^{-1}$ and four levels of K@0,10,20,30 kg ha ${ }^{-1}$ applied through Bentonite-S, and MOP respectively.

Available potassium in soil was extracted by Neutral normal ammonium acetate solution and potassium was determined using flame photometer (Jackson, 1967), available sulphur was determined by Turbid metric method given by Chesnin and Yien (1951). To carry out chemical analysis of plant, the randomly selected plot wise.

\section{Results and Discussion}

\section{Seed and straw yield of safflower}

From the data presented in table 2, revealed that the highest seed yield of safflower (15.02 $\mathrm{q} \mathrm{ha}^{-1}$ ) was obtained with application of $30 \mathrm{~kg}$ potassium $\mathrm{ha}^{-1}$ over all other levels of potassium. The significant increase in seed yield of safflower was recorded up to application of $30 \mathrm{~kg}$ potassium ha ${ }^{-1}$ with the increase supply of potassium. Similar results were reported by Abasiyeh et al., (2012) that increasing the levels of potassium there was a significant increased in seed yield of safflower. The response of sulphur to seed yield of safflower was significant with increasing levels of sulphur. The highest seed yield of safflower (14.65 $\left.\mathrm{q} \mathrm{ha}^{-1}\right)$ was recorded with the application of $30 \mathrm{~kg} \mathrm{~S} \mathrm{ha}{ }^{-1}, 10 \mathrm{~kg} \mathrm{~S}$ $\mathrm{ha}^{-1}\left(13.23 \mathrm{q} \mathrm{ha}^{-1}\right)$ and which was found to be at par with the application of $20 \mathrm{~kg}$ sulphur $\mathrm{ha}^{-1}\left(14.46 \mathrm{q} \mathrm{ha}^{-1}\right)$. The results are in conformity with the findings of Tetarwal et al., (2013) that seed and straw yield increased significantly up to $30 \mathrm{~kg} \mathrm{~S} \mathrm{ha}$. Piri and Sharma (2006) found that application of 15, 30 and $45 \mathrm{~kg} \mathrm{~S}^{-1}$ increase seed yield over control by 9,15 and $23 \%$, respectively.

Significant influence of sulphur on yield in safflower has also been observed by Dashora and Sharma (2006). Ravi et al., (2008) revealed that the higher seed yield $(1553 \mathrm{~kg}$ $\mathrm{ha}^{-1}$ ) was obtained with the higher sulphur levels $\left(30 \mathrm{~kg} \mathrm{~S} \mathrm{ha}^{-1}\right)$. This might be due to more accumulation of amino acids and amide substances and their translocation to reproductive organ, which influenced growth and yield due to sulphur application.

The interaction effect between $\mathrm{K}$ and $\mathrm{S}$ with respect to seed yield was found statistically significant. The maximum seed yield $(15.50 \mathrm{q}$ $\mathrm{ha}^{-1}$ ) was noticed with $\mathrm{K}_{30} \mathrm{~S}_{30}$ treatment combination which was found to be at par 
with $\mathrm{K}_{20} \mathrm{~S}_{30}\left(15.08 \mathrm{q} \mathrm{ha}^{-1}\right), \mathrm{K}_{20} \mathrm{~S}_{20}(14.96 \mathrm{q}$ $\left.\mathrm{ha}^{-1}\right), \quad \mathrm{K}_{30} \mathrm{~S}_{20} \quad\left(15.38 \mathrm{q} \quad \mathrm{ha}^{-1}\right)$ treatment combinations.

Content (\%) and uptake of nitrogen, phosphorus, potassium $\left(\mathrm{kg} \mathrm{ha}^{-1}\right)$ by safflower

The concentration of nitrogen in seed and straw was significantly increased up to $30 \mathrm{~kg}$ potassium $\mathrm{ha}^{-1}$. The total uptake on $\mathrm{N}$ was significantly increased with increase in potassium levels. The highest total uptake of $\mathrm{N}\left(67.52 \mathrm{~kg} \mathrm{ha}^{-1}\right)$ was obtained with the application of potassium at $30 \mathrm{~kg} \mathrm{ha}^{-1}$ which was significantly superior over lower levels of potassium application. The higher concentration of $\mathrm{N}$ in seed $(3.52 \%)$ and straw $(0.57 \%)$ was observed with the application of $30 \mathrm{~kg}$ sulphur ha ${ }^{-1}$, which was found to be at par with application of $20 \mathrm{~kg}$ sulphur $\mathrm{ha}^{-1}$ in seed $(3.48 \%)$ and straw $(0.56 \%)$. Highest total uptake of $\mathrm{N}\left(65.13 \mathrm{~kg} \mathrm{ha}^{-1}\right)$ was observed with the application of sulphur @ $30 \mathrm{~kg} \mathrm{ha}^{-1}$ which was found at par to application of $20 \mathrm{~kg}$ sulphur ha-1 $\left(63.00 \mathrm{~kg} \mathrm{ha}^{-1}\right)$.

The highest content of phosphorus in seed $(0.65 \%)$ and straw $(0.31 \%)$ was associated with the treatment $30 \mathrm{~kg}$ potassium $\mathrm{ha}^{-1}$ followed by application of $20 \mathrm{~kg}$ potassium $\mathrm{ha}^{-1}$ in seed $(0.63 \%)$ and straw $(0.28 \%)$ and lowest content was recorded in control. Total uptake of phosphorus found significantly more $\left(21.08 \mathrm{~kg} \mathrm{ha}^{-1}\right)$ with the application of $30 \mathrm{~kg}$ potassium $\mathrm{ha}^{-1}$, followed by application of 20 $\mathrm{kg}$ potassium ha ${ }^{-1}\left(19.46 \mathrm{~kg} \mathrm{ha}^{-1}\right)$ over no application of potassium. The $\mathrm{P}$ uptake significantly increased up to $30 \mathrm{~kg} \mathrm{~S} \mathrm{ha}{ }^{-1}$. It is clear from the data that, $\mathrm{P}$ content increases up to level of $30 \mathrm{~kg}$ sulphur ha- ${ }^{-1}$ and was found to be at par with $20 \mathrm{~kg} \mathrm{~S}^{-1}$ in seed $(0.62 \%)$ and straw $(0.30 \%)$. The highest total uptake of P (20.23 kg ha-1) was observed with the application of $30 \mathrm{~kg}$ sulphur ha ${ }^{-1}$. Tetarwal et al., (2013) also found that total uptake of phosphorus increased significantly. The highest total uptake of $\mathrm{P}\left(23.08 \mathrm{~kg} \mathrm{ha}^{-1}\right)$ was observed in $\mathrm{K}_{30} \mathrm{~S}_{30}$ treatment combination which was found to be at par with $\mathrm{K}_{20} \mathrm{~S}_{30}$ (21.53 kg ha $\left.{ }^{-1}\right), \mathrm{K}_{20} \mathrm{~S}_{20}\left(20.81 \mathrm{~kg} \mathrm{ha}^{-1}\right)$ and $\mathrm{K}_{30} \mathrm{~S}_{20}\left(22.71 \mathrm{~kg} \mathrm{ha}^{-1}\right)$. The lowest uptake of $\mathrm{P}$ $\left(12.23 \mathrm{~kg} \mathrm{ha}^{-1}\right)$ was observed in treatment combination $\left(\mathrm{K}_{0} \mathrm{~S}_{10}\right)$.

The application of $30 \mathrm{~kg}$ potassium $\mathrm{ha}^{-1}$ shows maximum content of $\mathrm{K}(1.23 \%$ in seed and $0.75 \%$ in straw) followed by application of 20 $\mathrm{kg}$ potassium $\mathrm{ha}^{-1}(1.18 \%$ in seed and $0.74 \%$ in straw). The total uptake of $\mathrm{K}$ was significantly increased with the increasing levels of potassium (Table 9 and fig. 8). The total uptake of $\mathrm{K}$ was found maximum $(45.96 \mathrm{~kg}$ $\mathrm{ha}^{-1}$ ) with application of potassium @ $30 \mathrm{~kg}$ $\mathrm{ha}^{-1}$, followed by potassium applied at $20 \mathrm{~kg}$ $\mathrm{ha}^{-1}\left(43.29 \mathrm{~kg} \mathrm{ha}^{-1}\right)$. Similar result found by Yadav et al., (2013) revealed that potassium application significantly increased the $\mathrm{K}$ content and $\mathrm{K}$ uptake in mustard crop which was significantly increased with the increasing levels of potassium. The higher percentage of potassium was recorded in seed $(1.19 \%)$ and straw $(0.76 \%)$ with the application of $30 \mathrm{~kg}$ sulphur ha ${ }^{-1}$ and was found to be at par with application of $20 \mathrm{~kg}$ sulphur ha ${ }^{-1}$ i.e. content of $\mathrm{K}$ in seed $(1.18 \%)$ and straw $(0.74 \%)$.

The lowest content of $\mathrm{K}$ was observed in seed $(1.14 \%)$ and in straw $(0.66 \%)$ with the application of $10 \mathrm{~kg} \mathrm{~S} \mathrm{ha}^{-1}$. The total uptake of $\mathrm{K}$ was increased significantly with increase in sulphur level. The highest uptake of K (44.63 $\mathrm{kg} \mathrm{ha}^{-1}$ ) was observed with application of 30 $\mathrm{kg}$ sulphur ha ${ }^{-1}$, followed by application of 20 $\mathrm{kg}$ sulphur ha ${ }^{-1}\left(42.47 \mathrm{~kg} \mathrm{ha}^{-1}\right)$. The maximum total uptake of $\mathrm{K}\left(49.58 \mathrm{~kg} \mathrm{ha}^{-1}\right)$ was obtained under $\mathrm{K}_{30} \mathrm{~S}_{30}$ treatment combination which was found to be more over $\mathrm{K}_{0} \mathrm{~S}_{10}$ treatment combination (31.74 $\left.\mathrm{kg} \mathrm{ha}^{-1}\right)$. Singh et al., (2013) reported that there was increase in total uptake of N, P, K and S with the application of $\mathrm{K}$ and $\mathrm{S}$. 
Table.1 Chemical properties at experimental site

\begin{tabular}{|l|l|l|}
\hline Sr.No. & Particulars & Analytical value \\
\hline $\mathbf{1}$ & $\mathrm{pH}(1: 2.5)$ & $\mathbf{7 . 9}$ \\
\hline $\mathbf{2}$ & EC $\left.(\mathrm{dSm})^{-1}\right)$ & $\mathbf{0 . 2 8}$ \\
\hline $\mathbf{3}$ & Organic carbon \% & $\mathbf{5 . 2 9}$ \\
$\mathbf{4}$ & Avail. $\mathbf{N}\left(\mathrm{kg} \mathrm{ha}^{-1}\right)$ & $\mathbf{1 7 4 . 2 0}$ \\
$\mathbf{5}$ & Avail. $\mathbf{P}_{2} \mathrm{O}_{5}\left(\mathrm{~kg} \mathrm{ha}^{-1}\right)$ & $\mathbf{1 5 . 5 3}$ \\
$\mathbf{6}$ & Avail. $\mathrm{K}_{2} \mathrm{O}\left(\mathrm{kg} \mathrm{ha}^{-1}\right)$ & $\mathbf{4 3 0 . 8}$ \\
$\mathbf{7}$ & Avail. Sulphur$\left(\mathrm{mg} \mathrm{ha}^{-1}\right)$ & $\mathbf{8 . 2 3}$ \\
\hline
\end{tabular}

Table.2 Seed and straw yield $\left(\mathrm{q} \mathrm{ha}^{-1}\right)$ of safflower as influenced by potassium and sulphur levels

\begin{tabular}{|c|c|c|}
\hline Treatments & Seed yield $\left(q\right.$ ha $\left.^{-1}\right)$ & Straw yield $\left(\mathbf{q} \mathbf{h a}^{-1}\right)$ \\
\hline \multicolumn{3}{|c|}{ Levels of Potassium $\left(\mathrm{kg} \mathrm{ha}^{-1}\right)$} \\
\hline $\mathbf{K}_{0}$ & 13.13 & 31.51 \\
\hline $\mathrm{K}_{10}$ & 13.77 & 33.05 \\
\hline $\mathrm{K}_{20}$ & 14.53 & 34.87 \\
\hline $\mathrm{K}_{\mathbf{3 0}}$ & 15.02 & 36.06 \\
\hline 'F' test & Sig. & Sig. \\
\hline $\mathrm{SE}(\mathrm{m}) \pm$ & 0.12 & 0.30 \\
\hline CD at 5\% & 0.36 & 0.88 \\
\hline \multicolumn{3}{|c|}{ Levels of sulphur $\left(\mathrm{kg} \mathrm{ha}^{-1}\right)$} \\
\hline$S_{10}$ & 13.23 & 31.75 \\
\hline $\mathbf{S}_{20}$ & 14.46 & 34.71 \\
\hline $\mathbf{S}_{\mathbf{3 0}}$ & 14.65 & 35.16 \\
\hline 'F' test & Sig. & Sig. \\
\hline $\mathrm{SE}(\mathrm{m}) \pm$ & 0.10 & 0.26 \\
\hline CD at 5\% & 0.31 & 0.76 \\
\hline \multicolumn{3}{|c|}{ Interaction (Potassium X Sulphur) } \\
\hline 'F' test & Sig. & Sig. \\
\hline $\mathrm{SE}(\mathrm{m}) \pm$ & 0.21 & 0.52 \\
\hline CD at $5 \%$ & 0.63 & 1.52 \\
\hline
\end{tabular}

Table.3 Interaction effects of potassium and sulphur on seed yield ( $\mathrm{q} \mathrm{ha}^{-1}$ ) of safflower

\begin{tabular}{|l|l|l|l|l|}
\multicolumn{1}{r|}{ Treatments } & \multicolumn{1}{c|}{$\mathrm{S}_{10}$} & \multicolumn{1}{c|}{$\mathrm{S}_{20}$} & \multicolumn{1}{c|}{$\mathrm{S}_{30}$} & \multicolumn{1}{c}{ Mean } \\
\hline $\mathrm{K}_{\mathbf{0}}$ & 12.38 & 13.17 & 13.85 & 13.13 \\
\hline $\mathrm{K}_{10}$ & 12.79 & 14.35 & 14.18 & 13.77 \\
\hline $\mathrm{K}_{20}$ & 13.56 & 14.96 & 15.08 & 14.53 \\
\hline $\mathrm{K}_{30}$ & 14.20 & 15.38 & 15.50 & 15.02 \\
\hline $\mathrm{Mean}$ & 13.23 & 14.46 & 14.65 & \\
\hline 'F' test & Sig. & & & \\
\hline $\mathrm{SE}(\mathrm{m}) \pm$ & 0.21 & & & \\
\hline CD at 5\% & 0.63 & & & \\
\hline
\end{tabular}


Table.4 Effect of potassium and sulphur on content (\%) and uptake of nitrogen, phosphorus, potassium $\left(\mathrm{kg} \mathrm{ha}^{-1}\right)$ by safflower

\begin{tabular}{|c|c|c|c|c|c|c|c|c|c|}
\hline & \multicolumn{2}{|c|}{$\begin{array}{c}\text { Nitrogen content } \\
(\%)\end{array}$} & \multirow{2}{*}{$\begin{array}{l}\text { Total N } \\
\text { uptake } \\
\text { (kg/ha) } \\
\text { total }\end{array}$} & \multicolumn{2}{|c|}{$\begin{array}{l}\text { Phosphorus } \\
\text { content }(\%)\end{array}$} & \multirow{2}{*}{$\begin{array}{l}\text { Total P } \\
\text { uptake } \\
\text { (kg/ha) } \\
\text { total }\end{array}$} & \multicolumn{2}{|c|}{$\begin{array}{c}\text { Potassium } \\
\text { Content (\%) }\end{array}$} & \multirow{2}{*}{$\begin{array}{c}\text { Total K } \\
\text { uptake } \\
\text { (kg/ha) } \\
\text { total }\end{array}$} \\
\hline & Seed & straw & & Seed & Straw & & Seed & straw & \\
\hline \multicolumn{10}{|c|}{ Levels of Potassium $\left(\mathrm{kg} \mathrm{ha}^{-1}\right)$} \\
\hline $\mathbf{K}_{0}$ & 2.53 & 0.48 & 54.29 & 0.53 & 0.24 & 14.76 & 1.10 & 0.66 & 35.82 \\
\hline $\mathbf{K}_{10}$ & 3.14 & 0.49 & 58.32 & 0.61 & 0.26 & 17.65 & 1.15 & 0.71 & 39.95 \\
\hline $\mathbf{K}_{20}$ & 3.47 & 0.54 & 63.89 & 0.63 & 0.28 & 19.46 & 1.18 & 0.73 & 43.29 \\
\hline $\mathrm{K}_{30}$ & 3.73 & 0.59 & 67.52 & 0.66 & 0.31 & 21.08 & 1.23 & 0.75 & 45.96 \\
\hline 'F' test & Sig. & Sig. & Sig. & Sig. & Sig. & Sig. & Sig. & Sig. & Sig. \\
\hline $\mathrm{SE}(\mathrm{m}) \pm$ & 0.11 & 0.01 & 0.59 & 0.08 & 0.10 & 0.38 & 0.021 & 0.007 & 0.64 \\
\hline CD at $5 \%$ & 0.33 & 0.04 & 1.73 & 0.24 & 0.27 & 1.11 & 0.061 & 0.020 & 1.93 \\
\hline \multicolumn{10}{|c|}{ Levels of Sulphur $\left(\mathrm{kg} \mathrm{ha}^{-1}\right.$} \\
\hline$S_{10}$ & 3.10 & 0.49 & 54.90 & 0.56 & 0.23 & 14.96 & 1.14 & 0.66 & 36.39 \\
\hline$S_{20}$ & 3.48 & 0.56 & 63.00 & 0.62 & 0.30 & 19.51 & 1.18 & 0.74 & 42.47 \\
\hline $\mathbf{S}_{30}$ & 3.52 & 0.57 & 65.13 & 0.63 & 0.31 & 20.23 & 1.19 & 0.76 & 44.63 \\
\hline 'F' test & Sig. & Sig. & Sig. & Sig. & Sig. & Sig. & Sig. & Sig. & Sig. \\
\hline $\mathrm{SE}(\mathrm{m}) \pm$ & 0.11 & 0.01 & 0.50 & 0.07 & 0.08 & 0.32 & 0.018 & 0.007 & 0.56 \\
\hline CD at $5 \%$ & 0.33 & 0.04 & 1.50 & 0.22 & 0.24 & 0.97 & 0.054 & 0.023 & 1.67 \\
\hline \multicolumn{10}{|c|}{ Interaction (Potassium x Sulphur) } \\
\hline 'F' test & N.S. & N.S. & Sig. & N.S. & N.S. & Sig. & N.S. & Sig. & Sig. \\
\hline $\mathrm{SE}(\mathrm{m}) \pm$ & 0.22 & 0.03 & 1.02 & 0.16 & 0.04 & 0.65 & 0.039 & 0.051 & 1.11 \\
\hline CD at $5 \%$ & - & - & 3.01 & - & - & 1.93 & - & 0.146 & 3.30 \\
\hline
\end{tabular}

Table.5 Effect of potassium and sulphur on quality of safflower

\begin{tabular}{|c|c|c|}
\hline Treatments & \multicolumn{2}{|c|}{ Content in seed (\%) } \\
\hline & Oil content $(\%)$ & Protein content (\%) \\
\hline \multicolumn{3}{|c|}{ Levels of Potassium $\left(\mathrm{kg} \mathrm{ha}^{-1}\right)$} \\
\hline $\mathbf{K}_{0}$ & 29.16 & 18.97 \\
\hline $\mathbf{K}_{10}$ & 30.23 & 19.22 \\
\hline $\mathbf{K}_{\mathbf{2 0}}$ & 30.30 & 19.48 \\
\hline $\mathbf{K}_{\mathbf{3 0}}$ & 30.32 & 19.53 \\
\hline 'F' test & Sig. & Sig. \\
\hline $\mathrm{SE}(\mathrm{m}) \pm$ & 0.012 & 0.32 \\
\hline CD at $5 \%$ & 0.040 & 0.96 \\
\hline \multicolumn{3}{|c|}{ Levels of Sulphur $\left(\mathrm{kg} \mathrm{ha}^{-1}\right)$} \\
\hline$S_{10}$ & 30.15 & 19.08 \\
\hline$S_{20}$ & 30.29 & 19.34 \\
\hline$S_{30}$ & 30.34 & 19.48 \\
\hline 'F' test & Sig. & Sig. \\
\hline $\mathrm{SE}(\mathrm{m}) \pm$ & 0.012 & 0.28 \\
\hline CD at $5 \%$ & 0.040 & 0.83 \\
\hline \multicolumn{3}{|c|}{ Interaction (Potassium x sulphur) } \\
\hline 'F' test & N.S. & N.S. \\
\hline $\mathrm{SE}(\mathrm{m}) \pm$ & 0.031 & 0.56 \\
\hline CD at $5 \%$ & - & - \\
\hline
\end{tabular}




\section{Quality of safflower}

The oil content of safflower seed increased from $29.16 \%$ in control to $30.32 \%$ at $30 \mathrm{~kg}$ potassium $\mathrm{ha}^{-1}$. Application of $30 \mathrm{~kg}$ potassium $\mathrm{ha}^{-1}$ shows maximum oil content $30.32 \%$ followed by $20 \mathrm{~kg}$ potassium $\mathrm{ha}^{-1}$ $(30.30 \%)$. It is evident from the data in the table 8 that successive increasing sulphur application from 10 to $30 \mathrm{~kg}$ sulphur ha ${ }^{-1}$ significantly increased the oil content in safflower seed. Application of $30 \mathrm{~kg}$ sulphur $\mathrm{ha}^{-1}$ recorded highest oil content $(30.34 \%)$ followed by $20 \mathrm{~kg}$ sulphur ha ${ }^{-1}(30.29 \%)$, whereas lowest value of oil content was recorded with the application of $10 \mathrm{~kg} \mathrm{~S} \mathrm{ha}^{-1}$. Oil storage organs of oil seed crops including safflower are mostly protein rich in sulphur and the supply of sulphur to these crops is paramount importance. The results are in agreement with the findings of Tetarwal et al., (2013) reported that the application of $30 \mathrm{~kg} \mathrm{~S}$ $\mathrm{ha}^{-1}$, recorded significantly higher oil content in seed than other treatment in mustard crop. Similar results were reported by Zizala et al., (2008) and Faisal et al., (2013) Chauhan (2013) reported that the seed oil content greatly influenced by various level of potash and sulphur. Protein content varied from 19.08 to $19.48 \%$ with increasing levels of sulphur from 10 to $30 \mathrm{~kg}$ sulphur ha ${ }^{-1}$ which were increased linearly over the lower level. Singh et al., (2008) reported that oil and protein yields were significantly increased by $\mathrm{N}$ and $\mathrm{S}$ levels due to increase in seed yields. Similar finding were reported by Panchal et al., (2011) and Zizala et al., (2008).

Ravi et al., (2008) stated that the data on oil content showed significant differences in oil content of safflower seeds due to sulphur application. The treatment receiving $30 \mathrm{~kg} \mathrm{~S}$ $\mathrm{ha}^{-1}$ resulted in the maximum oil content $(29.1 \%)$. This was significantly superior over $20 \mathrm{~kg} \mathrm{~S} \mathrm{ha}^{-1}(28.3 \%), 10 \mathrm{~kg} \mathrm{~S} h a^{-1}(26.9 \%)$ and control $(26.35 \%)$. This might be due to role of sulphur in synthesis of oil, sulphur is involved in the formation of glucosides and glcosinolates (mustard oil) and sulphydrillinkage and activation of enzyme which aid in the biochemical reaction within the plant. The treatment receiving $30 \mathrm{~kg} \mathrm{~S}^{-1}$ recorded the highest protein content $(14.63 \%)$ and it was significantly superior over $20 \mathrm{~kg} \mathrm{~S}$ ha ${ }^{1}(13.5 \%), 10 \mathrm{~kg} \mathrm{~S} \mathrm{ha}^{-1}(12.3 \%)$ and control $(11.3 \%)$.This is might be due to role of sulphur in protein synthesis. Sulphur is a constituent of essential amino acids viz. methionine, cysteine and cystine. These results are in support with the findings of Babhulkar et al., (2000), in safflower and Shekhargouda et al., (1997) in safflower lend support to this study.

The application of potassium up to $20 \mathrm{~kg} \mathrm{ha}^{-1}$ and sulphur up to $20 \mathrm{~kg} \mathrm{ha}^{-1}$ significantly influence the seed and straw yield of safflower. The concentration and uptake of $\mathrm{N}$, $\mathrm{P}, \mathrm{K}$ and $\mathrm{S}$ also improved in seed and straw of safflower. Application of potassium and sulphur improves the quality of seed in safflower by increasing oil and protein content. Application of potassium and sulphur help to improve the availability of $\mathrm{N}, \mathrm{P}, \mathrm{K}$, and $\mathrm{S}$ in the soil.

\section{References}

Abasiyeh, S.K., A.H.S. Rad, B. Delkhoush and H. Nasrollahi, 2012. Effect of potassium and zeolite on seed, oil and, biological yield in safflower, Annals of Biological Research 4(5): 204-207

Anonymous, 2014 (a). Ministry of Agriculture, Govt. of India.

Babhulkar, P.S., K. Dineskar, W.P. Badole and S.S. Balpande, 2000. Effect of sulphur and zinc on yield, quality and nutrient uptake by Safflower in Vertisols. J. Indian Soc. Soil Sci. 48: 541-543.

Chauhan Sandhya, A. Titov and D.S. Tomar, 
2013. Effect of potassium, sulphur and zinc on growth, yield and oil content in soybean (Glycine max L.) in Vertisols of central India. Indian Journal of Applied Research 3:461-62

Chesnin, L. and C.H. Yien, 1951. Turbidimetric determination of available sulphur in soil. Soil Sci. Soc. of America Proceedings 15: 149-151.

Chiddha Singh, 1998. Importance of safflower in modern techniques of raising field crops. Oxford and IBH publishing Co. Bombay, pp. 301.

Dajue, L. and H.H. Mundel, 1996. Safflower promoting the conservation and use of underutilized neglected crop. Institute of plant genetics and crop plant research, International plant genetic resources institute, Rome, Italy pp. 85

Dashora, P. and Sharma, R.P, 2006. Effect of sowing date, irrigation and sulphur nutrition on yield attributes, yield and oil content of safflower. Crop Res. Hisar 31: 56-57.

Ekin, Z., 2005. Resurgence of Safflower (Carthamus tinctorious L.) utilization a global view, J.Aron. 4:83-87

Faisal, R.U., B. Hassan and I. A. Rasool, 2013. Effect of sulphur levels on growth and yield of sunflower. Indian J. Agric. Res.29 (2): 50-52.

Ghosh, D.C., P.K. Panda and P.M. Sahu, 1995. Response of rainfed rapeseed (Brassica campestris L.) to $\mathrm{N}, \mathrm{P}, \mathrm{K}$. Indian J. Agric. Res. 29(1): 5-9.

Jackson, M.L., 1967. Soil chemical analysis, prentice hall of India, private limited New Delhi.

Kandpal, B.H. and A.S. Chandel, 1993. Effect of gypsum and pyrite as source of sulphur on nitrogen fixation, dry matter yield and quality of soybean, Indian Journal of Agronomy 38(1): 137-139

Kuo, N.C. and Chen, 1980. Response of agronomic characters, seed yield, oil content and fatty acid composition rape seed to NPK fertilizer treatments. J. Agric. Assoc. China.11:23-35.

Panchal, D.B., R.D. Siyolkar, K.H. Patel and B.T. Sheta, 2011. Effect of nitrogen and sulphur application on yield and nutrient uptake by mustard. GAU Research J. 36 (1): 31-33.

PiriIssa and S.N. Sharma, 2006.Effect of levels and sources of sulphur on yield attributes, yield and quality of Indian mustard (Brassica juncea). Indian J. Agro. 51 (3): 217-220.

Ravi, S., H.T. Channal, N.S. Hebsur, B.N. Patil and P.R. Dharmatti, 2008. Effect of sulphur, zinc and iron nutrition on growth, yield, nutrient uptake and quality of Safflower (Carthamus tinctorius L.). Karnataka J. Agric. Sci. 21(3): 382-385.

Saalbach, E., 1973. The effect of S, Mg and $\mathrm{Na}$ on yield and quality of agriculture crop. In pontificial Academical Scientiarum Scripta Varia 38: 451-538.

Shekharagouda, M., R. Hunje, B. Patil and K. Manjappa, 1997. Effect of sulphur and zinc on the growth and yield of safflower. Karnataka J. Agric. Sci. 10(3): 766-771.

Singh, A.K., S. N. Singh, O. P. Singh, and M. A. Khan, 2008. Quality of Indian mustard (Brassica juncea L.) as affected by nitrogen and sulphur fertilizers in a nutrient deficient soil. Indian $\mathbf{J}$ Agric Boichem. 21(1 and 2): 39-41.

Singh, H.G. and M.P. Sahu, 1986. Response of oilseeds to sulphur. Fertil. News 31(9): 23-30.

Singh, J.P., K.S. Grewal and R.S. Antil, 2013. Significance of potassium use in Haryana agriculture. Indian J. Fert. 10(2): 30-38.

Tetarwal, J.P., B. Ram, D.S. Meena and S.S. Tomar, 2013. Effect of moisture conservation and sulphur sources on productivity and water use efficiency of 
Indian mustard (Brassica juncea) under rainfed conditions. Indian J. Agro. 58(2): 231-236.

Yadav, S.S., Abha Tikkoo and J.P. Singh, 2013. Potassium response in Indian safflower in coarse textured soils of Southern Haryana, Journal of the Indian
Society of Soil Science 61(2): 107-111

Zizala, V.J., N.B. Jadav and P.S. Gorfad, 2008. Effect of sulphur and zinc on yield, quality and its concentration on safflower. Asian J. Soil Sci. 3 (1): 173177.

\section{How to cite this article:}

Dipak Salve, Monika S. Bhavsar, Rajanikant B. Ghagare and Sugandh N. Shinde. 2018. Effect of Potassium and Sulphur on Nutrient Uptake, Yield and Quality of Safflower in Vertisol. Int.J.Curr.Microbiol.App.Sci. 7(01): 1116-1123. doi: https://doi.org/10.20546/ijcmas.2018.701.135 